\title{
IN VITRO HEPATIC BIOTRANSFORMATION OF ALDRIN AND DIELDRIN IN FOOD-PRODUCING ANIMALS
}

\author{
N. FURUSAWA ${ }^{*}$ and Y. MORITA \\ Faculty of Human Life Science, Osaka City University, Osaka 558-8585, Japan
}

(Received January 2, 2001; accepted May 17, 2001)

\begin{abstract}
The hepatic biotransformation of aldrin (AD) and dieldrin (DD) was studied in liver post-mitochondrial supernatants (S-9s) from laying hens, female cattle and swine. S-9s were incubated with 0.03 nmol of AD or DD for $1 \mathrm{~h}$. After $1 \mathrm{~h}$, $\mathrm{AD}$ in the samples was almost epoxidated to DD. This formation was found with all the animal S-9s, and the highest rates occurred in pig S-9 $(\mathrm{P}<0.01)$, followed by cow and hen S-9s. No reduction of DD was found with any of the S-9s.
\end{abstract} ing animals

Key words: Aldrin, dieldrin, epoxidation, biotransformation, food-produc-

Aldrin (1,2,3,4,10,10-hexachloro-1,4,4a,5,8,8a-hexahydro-1,4:5,8-dimethanonaphthalene, AD) and its epoxide, dieldrin $(1,2,3,4,10,10$-hexachloro-6,7epoxy-1,4,4a,5,6,7,8,8a-octahydroendo-,exo-1,4:5,8-dimethanonaphthalene, DD), still appear as residues in livestock products. Since they are persistent, lipoid compounds, they bio-concentrate in the food chain and are accumulated in the fat. These compounds appear persistently in food-producing animals and in their products such as meat, milk and eggs indirectly, as a result of environmental contamination of the diet. AD and DD have received much attention as 'endocrine-disrupting chemicals' (EPA, 1997; Kavlock, 1996) and carcinogenic substances (IARC, 1987). Knowledge of the biotransformation of AD and DD in the above animals is essential to determine the duration of accumulation and the toxicity of the compounds.

Epoxides are reduced by epoxide hydrolases (EHase): mEHase in the microsomal fraction and cEHase in the soluble (cell sap) fraction. EHase is widely distributed in the tissues of various animals and humans. In male rats it occurs in almost all tissues examined (liver, testes, kidney, lungs and adrenal gland), with the highest activity being found in the liver (Gibson and Skett, 1994a; Yamamoto, 1995b). However, no paper has been published on the hepatic reduction of DD in animals.

In vitro experiments are a convenient, up-to-date and economical model of drug metabolism, and require the use of fewer animals and shorter experimental

*Corresponding author; E-mail: furusawa@life.osaka-cu.ac.jp; Fax: +81-6-6605-2864 
time, in contrast to in vivo experiments of the target drugs using a large number of live animals. Little is known about the in vitro biotransformation of $\mathrm{AD}$ or $\mathrm{DD}$ in food-producing animals. Comparative studies in different species of animals are needed not only for judging the safety of $\mathrm{AD}$ or $\mathrm{DD}$ but also to provide the basic data that could clarify possible interspecies variations in drug metabolism (Weber, 1983; Gregus et al., 1983).

This communication presents the in vitro hepatic biotransformation profiles of AD and DD in some food-producing animals, such as laying hens, cattle and swine. The experiment used the post-mitochondrial supernatant (S-9) containing the microsomal (mEHase) plus soluble (cell sap) (cEHase) cell fractions.

\section{Materials and methods}

\section{Drugs and animals}

$\mathrm{AD}$ and $\mathrm{DD}$ standards were obtained from Wako Pure Chem. Ltd. (Osaka, Japan).

Six Brown Leghorn laying hens aged 17 months, given a drug-free basal diet and tap water ad libitum, were slaughtered and the livers were collected. Livers of five healthy cows aged 12 months and five female pigs aged 6 months were purchased from Osaka City Meat Inspection Office (Osaka, Japan). These animals had not been treated with drugs for at least one month prior to slaughtering.

\section{Experimental design}

The liver tissues were prepared as follows. All apparatuses, solutions and the liver tissues were kept at a temperature not exceeding $4{ }^{\circ} \mathrm{C}$ throughout preparation and isolation. A $20 \%(\mathrm{w} / \mathrm{v})$ homogenate was made in $1.15 \% \mathrm{KCl}$ solution using a glass Potter-type homogenizer with a Teflon pestle (Teflon ${ }^{\circledR}$ Homogenizer, Masuda Co., Osaka, Japan). To prepare the post-mitochondrial supernatant (S-9), the homogenate was centrifuged with $4{ }^{\circ} \mathrm{C}$ at $9000 \mathrm{~g}$ for $15 \mathrm{~min}$ $\left(\right.$ at $2{ }^{\circ} \mathrm{C}$ ) in a refrigerated centrifuge. The resulting supernatant, S-9, was reserved and stored at $-80^{\circ} \mathrm{C}$ until used.

The total protein level was determined by a commercial kit (A/G B-test Wako $^{\circledR}$, Wako Pure Chem., Ltd., Osaka, Japan) as the standard protein of bovine serum origin, according to the biuret method using copper sulphate pentahydrate $\left(\mathrm{CuSO}_{4} \times 5 \mathrm{H}_{2} \mathrm{O}\right)$.

The biotransformation of S-9s was assayed in conformity with a procedure described previously (Gibson and Skett, 1994b). That is, S-9s were incubated with $\mathrm{AD}(0.03 \mathrm{nmol})$ in an incubation mixture $(0.1 \mathrm{~mol}$ phosphate buffer, $\mathrm{pH} 7.3)$ containing an NADPH-generating system $\left(0.45 \mu \mathrm{mol} \mathrm{NADP}^{+}, 20.0 \mu \mathrm{mol}\right.$ 
glucose-6-phosphate, $50 \mu \mathrm{mol} \mathrm{MgCl}_{2} \times 6 \mathrm{H}_{2} \mathrm{O}$ and $7.5 \mu$ mol nicotinamide) at $37^{\circ} \mathrm{C}$ or $41^{\circ} \mathrm{C}$ for $1 \mathrm{~h}$, in triplicate. After $1 \mathrm{~h}$, the mixture sample was put in a boiling water bath for 10 min to terminate the enzyme reaction. The blank sample incubations were prepared as above, but by substituting a tissue homogenate previously heated to $80-100{ }^{\circ} \mathrm{C}$ for $10 \mathrm{~min}$ to denature the enzymes. Moreover, the suitable blank was prepared by replacing AD with 0.1 mol phosphate buffer ( $\mathrm{pH} 7.4)$.

For reduction of DD in the $\mathrm{S}-9 \mathrm{~s}$, the experiment using $\mathrm{DD}(0.03 \mathrm{nmol})$ was conducted in the above manner.

Analysis

Quantitative analysis for the target compound in $0.2 \mathrm{ml}$ of the mixture sample was performed by the extraction and GC determination described previously (Furusawa et al., 1998, 1999). Qualitative confirmations were achieved by comparing the retention times obtained on the two GC columns with different polarities under the same GC conditions, using electron capture detector (ECD).

\section{Statistical analysis}

For the biotransformation rates in the hen, cow and pig S-9s, the significance of difference between means was examined by Studentized Tukey's test with one-way analysis of variance. The analysis was accomplished using SAS ${ }^{\circledR}$ software (SAS Institute, 1994).

\section{Results and discussion}

In GC traces of the blank and spiked S-9 samples obtained under the $\mathrm{AD} / \mathrm{DD}$-determining method used here, the resulting extracts were free from interfering compounds for detection in the GC traces (chromatograms not shown). By the analytical method used in this study, the recovery rate of AD and DD from the incubation medium of hen, cow and pig samples was determined at spiking levels of $0.005 \mathrm{nmol}$ and $0.01 \mathrm{nmol}$ simultaneously. Average recoveries were higher than $88 \%$ with coefficients of variation within $8 \%(n=5)$, which are considered to be satisfactory. The limit of determination for both AD and DD was 0.6 pmol.

Table 1 summarizes the biotransformation rates in S-9s from hens, cows and female pigs. The epoxidation of $\mathrm{AD}$ occurred at the highest rate in the pig S-9 $(\mathrm{P}<0.01)$. No decrease of DD content was detected in any of the incubated samples, indicating a lack of DD reduction.

Since the body temperature of laying hens $\left(41^{\circ} \mathrm{C}\right)$ is higher than that of other species $\left(37-39^{\circ} \mathrm{C}\right.$ ) (Mizutani, 1990), the hen samples were incubated at 
both $41{ }^{\circ} \mathrm{C}$ and $37{ }^{\circ} \mathrm{C}$ in the present study. There was no significant difference in epoxidation depending on the incubation temperature (Table 1).

In the present study, DD, an olefin oxide, was not reduced by liver S-9s from hen, cows and female swine. Similar findings have been reported for olefin oxides such as benzo[a]pyrene oxide in mammalian liver in vitro (Sugiura et al., 1980; Hirano et al., 1994). These findings suggest that olefin oxides, like DD, cannot be reduced in the animal liver. It has been known that (1) the order of toxicity of AD and DD to animals and humans is DD > AD; (2) DD is metabolized to 6,7-transdihydroxy dihydroaldrin by EHase and loses its effect/toxicity (Yamamoto, 1995a). The present findings may therefore facilitate the evaluation of toxicological activity and accumulation of DD in animals.

Table 1

Biotransformation rates of aldrin (AD) and dieldrin (DD) in animal liver S-9 ${ }^{1}$

\begin{tabular}{lccc}
\hline Species & $\begin{array}{c}\text { Incubation } \\
\text { temperature }\left({ }^{\circ} \mathrm{C}\right)\end{array}$ & $\begin{array}{c}\text { Epoxidation }^{2} \\
\text { of AD }\end{array}$ & $\begin{array}{c}\text { Reduction } \\
\text { of DD }\end{array}$ \\
\hline Hens & 41 & $2.23 \pm 1.19^{\mathrm{b}}$ & none \\
& 37 & $2.10 \pm 0.98^{\mathrm{b}}$ & none \\
Cows & 37 & $3.26 \pm 0.61^{\mathrm{b}}$ & none \\
Pigs (female) & 37 & $5.99 \pm 1.06^{\mathrm{a}}$ & none \\
\hline
\end{tabular}

${ }^{1}$ Liver post-mitochondrial supernatants; ${ }^{2}$ Data are expressed as mean formation rates $\left(\times 10^{-2} \mathrm{nmol} /\right.$ $\mathrm{mg}$ protein $/ \mathrm{h}) \pm \mathrm{SD}(\mathrm{n}=3)$ from $\mathrm{AD}$ to $\mathrm{DD} ;{ }^{3}$ Decrease rates of DD. Means with different superscripts $\left({ }^{\mathrm{a}, \mathrm{b}}\right)$ in the same column differ significantly $(\mathrm{P}<0.01)$

Furusawa and Morita (2000) have reported contaminating/accumulating levels of AD, DD and DDTs in the diet, eggs and various tissues (adipose tissue, blood, kidney, liver, muscle, ovary and oviducts) of laying hens kept on a common Japanese poultry farm. DD was detected in all the samples examined in concentrations ranging from 4 to $58 \mathrm{ppb}$ (fat base). On the other hand, no AD was detected in any of the above samples ( $<1$ ppb fat base). In laying hens, the in vitro data shown in Table 1 support the maintenance of DD accumulated in the body fat of hens for a long period of life.

The present study shows that although $\mathrm{AD}$ was epoxidated rapidly in the hen, cow and pig liver S-9s, its epoxide, DD, was not reduced. 


\section{References}

EPA (1997): Special Report on Environmental Endocrine Disruption. In: An Effects Assessment and Analysis. U.S. p.111.

Furusawa, N. and Morita, Y. (2000): Polluting profiles of dieldrin and DDTs in laying hens of Osaka, Japan. J. Vet. Med. A 47, 511-515.

Furusawa, N., Okazaki, K., Iriguchi, S., Yamaguchi, H. and Saitoh, M. (1998): Gel permeation and florisil chromatographic cleanup and gas chromatographic determination of organochlorine pesticides in eggs. J. AOAC Int. 81, 1033-1036.

Furusawa, N., Ozaki, A., Nakamura, M., Morita, Y. and Okazaki, K. (1999): Simple and rapid extraction method of total egg lipids for determining organochlorine pesticides in the egg. J. Chromatogr. A 830, 473-476.

Gibson, G. G. and Skett, P. (1994a): Enzymology and molecular mechanisms of drug metabolism reactions. In: Gibson, G. G. and Skett, P. (eds) Introduction to Drug Metabolism. 2nd edition. Chapman \& Hall Press, London. pp. 35-76.

Gibson, G. G. and Skett, P. (1994b): Techniques and experiments illustrating drug metabolism. In: Gibson, G. G. and Skett, P. (eds) Introduction to Drug Metabolism. 2nd edition. Chapman \& Hall Press, London. pp. 217-256.

Gregus, Z., Watkins, J. B., Thompson, T. N., Harvey, M. J., Rozman, K. and Klaassen, C. D. (1983): Hepatic phase I and phase II biotransformations in quail and trout: Comparison to other species commonly used in toxicity testing. Toxicol. Appl. Pharm. 67, 430-441.

Hirano, Y., Kitamura and Tatsumi, K. (1994): Epoxide reductase activity of mammalian liver cytosols and aldehyde oxidase. Carcinogenesis 15, 739-743.

IARC (1987): Monographs or the evaluation of carcinogenic risks to humans (Suppl. 7). The International Agency for Research on Cancer.

Kavlock, R. J. (1996): Research Needs for the Risk Assessment of Health and Environmental Effects of the U.S. EPA-sponsored Workshop. Environ. Health Perspect. 104 (Suppl. 4), pp. 714-740.

Mizutani, M. (1990): Experimental Animals for Toxicity Tests. In: Fujiwara, K. and Horiuchi, S. (eds) Chijin Syokan Press, Tokyo. pp. 101-110.

SAS Institute (1994): SAS ${ }^{\circledR}$ User's Guide, Version 6, Firth Edition, Vol. 1 \& 2, Cary, NC.

Sugiura, M., Yamazoe, Y., Kamataki, T. and Kato, R. (1980): Reduction of epoxy derivatives of benzo(a)pyrene by microsomal cytochrome P-450. Cancer Res. 40, 739-743.

Yamamoto, I. (1995a): Dictionary of Drug Metabolism. In: Yamamoto, I. (ed.) Hirokawa Publishing Co., Tokyo. p. 37.

Yamamoto, I. (1995b): Dictionary of Drug Metabolism. In: Yamamoto, I. (ed.) Hirokawa Publishing Co., Tokyo. pp. 79-80.

Weber, N. E. (1983): Metabolism and kinetics in the regulation of animal drugs. J. Anim. Sci. 56, $224-254$. 